\title{
Hubungan Pengetahuan dengan Tingkat Kecemasan Remaja Putri Menghadapi Menarche di SMP Negeri 13 Kota Jambi
}

\author{
Fatihatul Hayati ${ }^{1}$, Gustina ${ }^{2}$ \\ ${ }^{1,2}$ Program Studi DIII Kebidanan STIKes Baiturrahim Jambi \\ Email: fatihatulhayatianam@gmail.com
}

Submitted : 20/11/2019

Accepted: 06/02/2020

Published: 07/09/2020

\begin{abstract}
Adolescence is a transitional period involving physical, emotional, and social development experienced by young women as a process of preparation for entering adulthood. In general, physical changes tend to be more dominating. Young women and menstruation have a very close relationship because menstruation is one of the important issues in young women. This study aims to determine the relationship between knowledge and anxiety levels of young women in the face of menarche. Subjects in this study were all students of SMP Negeri 13 Jambi City with a sample of 40 people. The sampling technique is proportional random sampling. Teenage anxiety levels were measured using the Hamilton Anxiety Rating Scale (HARS) questionnaire. There is a significant relationship between knowledge and anxiety levels of young women in the face of the first menstruation (menarche). It is hoped that there will be efforts to increase adolescent knowledge about reproductive health, especially menstrual preparation in the form of school programs in collaboration with local health centers.
\end{abstract}

Keywords: anxiety, menarche, teenagers

Abstrak

Masa remaja merupakan masa peralihan meliputi perkembangan fisik, emosional, maupun sosial yang dialami remaja putri sebagai proses persiapan memasuki masa dewasa. Secara umum perubahan fisik cenderung lebih mendominasi..Remaja putri dan menstruasi mempunyai kaitan yang sangat erat karena menstruasi merupakan salah satu permasalahan yang penting pada remaja putri. Penelitian ini bertujuan untuk mengetahui hubungan antara pengetahuan dengan tingkat kecemasan remajaputri dalam menghadapi menarche. Subjek pada penelitian ini adalah seluruh siswi SMP Negeri 13 Kota Jambi dengan sampel berjumlah 40 orang. Teknik pengambilan sampel secara proporsional random sampling. Tingkat kecemasan remaja putri diukur menggunakan kuesioner Hamilton Anxiety Rating Scale (HARS). Ada hubungan bermakna antara pengetahuan dengan tingkat kecemasan remaja putri dalam menghadapi haid pertama (menarche). Diharapkan ada upaya peningkatan pengetahuan remaja tentang kesehatan reproduksi terutama persiapan menstruasi dalam bentuk program sekolah yang bekerja sama dengan Puskesmas setempat.

Kata Kunci : kecemasan, menarche, remaja

\section{PENDAHULUAN}

Masa remaja merupakan masa peralihan dari masa kanak-kanak ke masa dewasa yang meliputi semua perkembangan seperti perkembangan fisik, emosional, maupun sosial yang akan dialami remaja putri sebagai proses persiapan memasuki masa dewasa. Secara umum, di antara perubahan yang terjadi pada masa ini, perubahan fisik cenderung lebih mendominasi karena merupakan salah satu ciri yang penting dari perkembangan masa remaja. Perubahan fisik yang terjadi antara anak laki - laki dan perempuan sangatlah berbeda, pada anak laki - laki perubahan fisik ditunjukkan dengan pertumbuhan batang kemaluan (penis) dan kantung kemaluan (scrotum) atau biasa ditandai dengan mimpi basah. Sementaraitu, pada anak perempuan terjadi perubahan pada payudara dan alat kemaluan (vagina) atau biasa ditandai dengan munculnya menstruasi pertama kali atau menarche 
(Rumini, 2004; Mar'at, 2005).

Remaja putri dan menstruasi mempunyai kaitan yang sangat erat karena menstruasi merupakan salah satu permasalahan yang penting pada remaja putri. Remaja putri dikatakan sudah memasuki masa pubertas ketika ia telah mengalami menstruasi. Di Amerika sekitar $95 \%$ anak perempuan mempunyai tanda pubertas pada usia 10-15 tahun, tetapi sebagian besar anak perempuan mempunyai tanda pubertas pada usia 12,5 tahun. Namun, ada juga yang mengalami lebih cepat atau bahkan dibawah usia tersebut. Kedatangan menarche inisering kali dianggap sebagai suatu penyakit, sehingga menarche tersebut memicu timbulnya kecemasan. Prawirohardjo, 2012; Dariyo, 2004).

Menstruasi merupakan proses biologis yang terkait dengan pencapaian kematangan seks, kesuburan, ketidak hamilan, normalitas, kesehatan tubuh, dan bahkan pembaharuan tubuh itu sendiri. Secara Kematangan seksual (menstruasi, kematangan fisik) ini disebabkan antara lain oleh konstitusi fisik individual, ras, suku bangsa, iklim, cara hidup, dan lingkungan. Kondisi fisik yang kurang terjaga atau penyakit yang dialami seorang remaja puteri dapat memperlambat datangnya menstruasi (Judha, 2009).

Menstruasi pertama (menarche) merupakan menstruasi awal yang biasa terjadi dalam rentang usia sepuluh tahun sampai enam belas tahun, atau pada masa awal remaja dan sebelum memasuki masa reproduksi. Pengertian menstruasi adalah pendarahan periodic dan siklik dari uterus disertai dengan pengelupasan (deskuamasi) endometrium. Menstruasi pertama (menarche) merupakan peristiwa terpenting yang terjadi pada masa remaja. Hal ini dinyatakan oleh Yeung, Tang dan Lee (2005) bahwa menstruasi pertama (menarche) merepresentasikan simbol masa transisi dari anak-anak menuju masa dewasa (Proverawati, 2007; Llewellyn, 2005).
Rata-rata usia menarche di Indonesia yaitu usia 11,2 -13,4 tahun, dengan umur terendah 9 tahun dan tertinggi 15 tahun. Berdasarkan status social ekonomi pada golongan social ekonomi rendah rata-rata usia menstruasi pertama (menarche) 9,615,6 tahun, sedangkan golongan social ekonomi tinggi rata-rata usia menstruasi pertama (menarche) 9,8-13,8 tahun (Ginarhayu, 2014).

Menarche dapat menimbulkan perubahan psikologis bagi remaja putri, diantaranya yaitu perubahan aspek psikologis yang terjadi pada remaja putri, dapat berupa emosional yaitu perasaan cemas. Contoh dari perubahan psikologis pada rasa cemas yang dirasakan remaja seperti rasa terkejut bahkan trauma, rasa takut, bersikap irasional serta mudah tersinggung. Hal ini sesuai dengan yang diungkapkan Kartono (2006) bahwa gejala yang sering terjadi dan sangat mencolok pada peristiwa menarche adalah ketakutan dan kecemasan (Kartono, 2006).

Kecemasan merupakan respon dari individu terhadap suatu keadaan yang tidak menyenangkan dan dialami oleh semua makhluk hidup dalam kehidupan sehari-hari dan digolongkan ke dalam pengalaman yang tidak menyenangkan yang biasanya di tandai dengan beberapa gejala seperti jantung yang berdebar-debar, sesak nafas, perasaan khawatir, rasa takut yang tidak normal, rasa ragu pada diri sendiri, dan merasa adanya ancaman.(Nainggolan, 2013). Berdasarkan fenomena tersebut peneliti tertarik untuk melakukan penelitian yang berjudul "Hubungan Pengetahuan dengan Tingkat Kecemasan Remaja Putri Menghadapai Menarche"

\section{METODE PENELITIAN}

Penelitian ini merupakan penelitian analitik yaitu suatu penelitian yang bertujuan untuk menganalisis didalam suatu komunitas atau kelompok masyarakat. Penelitian ini bertujuan untuk mengetahui hubungan antara pengetahuan dengan 
tingkat kecemasan remaja putri dalam menghadapi menarche.

Adapun lokasi dalam penelitian ini bertempat di SMP Negeri 13 Kota Jambi. Sampel dalam penelitian ini adalah siswi SMP Negeri 13 Kota Jambi sebanyak 40 orang, dengan teknik pengambilan sampel proporsional random sampling. Jenis data yang digunakan adalah data primer. Sumber data penelitian ini adalah hasil wawancara dengan siswi tentang pengetahuan dan tingkat kecemasan menghadapi menarche. Instrumen pengumpulan data dengan menggunakan kuesioner yang telah dibuat sebelumnya. Panduan pertanyaan kuesioner berisi pengetahuan tentang fisiologi menarche dan menstruasi serta kecemasan berdasarkan Hamilton Anxiety Rating Scale (HARS).

\section{HASIL DAN PEMBAHASAN}

A. Gambaran Pengetahuan Remaja Putri Tentang Haid Pertama (Menarche)

Berdasarkan hasil penelitian diketahui distribusi pengetahuan remaja putri tentang haid pertama (menarche) di SMPN 13 Kota Jambi dapat dilihat pada table 1 berikut ini:

Tabel 1. Distribusi Frekuensi Pengetahuan Remaja Putri Tentang Haid Pertama (Menarche)

\begin{tabular}{ccc}
\hline Pengetahuan & Frekuensi (n) & $\begin{array}{c}\text { Presentase } \\
(\%)\end{array}$ \\
\hline Baik & 17 & 42.5 \\
Cukup & 16 & 40 \\
Kurang & 7 & 17.5 \\
\hline Jumlah & 40 & 100
\end{tabular}

Berdasarkan tabel 1 dapat di

ketahui bahwa sebagian besar remaja putri memiliki pengetahuan baik yaitu 17 orang $(42.5 \%)$. Dari penelitian ini diketahui bahwa pengetahuan seseorang dapat dipengaruhi oleh beberapa faktor salah satunya usia dan lingkungan. Semakin baik lingkungan tersebut maka cara untuk memperoleh pengetahuan pun sangat mudah. Kemudahan memperoleh informasi akan meningkatkan peluang seseorang memiliki pengetahuan lebih baik. Dan usia menjadi penunjang untuk menerima dan menerapkan informasi yang didapat.

Penelitian ini sejalan dengan penelitian yang dilakukan oleh Yati Dkk 2014 yang melakukan penelitian tentang Hubungan pengetahuan menarche dengan kesiapan remaja putri menghadapi menarche di SMP negeri 3 tidore kepulauan didapatkan kesimpulan hasil sebagai berikut, Pengetahuan siswi tentang menarche di SMP Negeri 3 Tidore Kepulauan berada dalam kategori cukup $(45,7 \%)$. Kesiapan siswi dalam menghadapi menarche di SMP Negeri 3 Tidore Kepulauan berada dalam kategori siap $(62,9 \%)$. Ada hubungan antara pengetahuan menarche dengan kesiapan remaja putri menghadapi menarche di SMP Negeri 3 Tidore Kepulauan.

\section{B. Gambaran Tingkat Kecemasan Remaja Putri Tentang Haid Pertama (Menarche)}

Berdasarkan hasil penelitian diketahui frekuensi tingkat kecemasan remaja putri tentang haid pertama (menarche) di SMPN 13 Kota Jambi dominan pada skala sedang. Tabel 2. Distribusi Frekuensi Tingkat Kecemasan Remaja Putri Tentang Haid Pertama (Menarche)

\begin{tabular}{ccc}
\hline Kecemasan & $\begin{array}{c}\text { Frekuensi } \\
(\mathrm{n})\end{array}$ & Persentase (\%) \\
\hline Ringan & 6 & 15 \\
Sedang & 30 & 75 \\
Berat & 4 & 10 \\
\hline Jumlah & 40 & 100
\end{tabular}

Berdasarkan tabel 2 diketahui bahwa sebagian besar remaja putri dengan tingkat kecemasan sedang sebanyak 30 orang $(75 \%)$ dan tidak ada remaja putri yang mengalami kecemasan ringan.

Dari hasil penelitian ini dapat dilihat bahwa kecemasan memasuki menarche banyak dialami oleh siswi di SMP N 11 kota Jambi. Ini terjadi dikarenakan 
menarche merupakan peristiwa yang dapat memicu kecemasan bagi siswi, dikarenakan periode ini terjadi sebagai penanda masa pubertas remaja, dengan keluarnya darah dan berbagai tanda-tanda yang dialami oleh siswi.

Hal ini sesuai dengan penelitian Imam Zainuri dan Ella (2012) hasil penelitian menunjukkan dari 19 siswi yang diteliti didapatkan bahwa $16 \quad(84,2 \%)$ diantaranya kecemasan sedang dan sisaya 3 $(15,8 \%)$ tingkat kecemasannya berat sedangkan pengetahuan tentang menarche semakin sedikit kecemasannya, dan sebaliknya kurang pengetahuannya tentang menarche semakin tinggi pula tingkat kecemasannya (Imam, 2012).

\section{Hubungan Pengetahuan dengan Tingkat Kecemasan Remaja Putri Menghadapai Menarche}

Tabel 3. Hubungan Pengetahuan dengan Tingkat Kecemasan Remaja Putri Menghadapi Menarche

\begin{tabular}{|c|c|c|c|c|c|c|c|}
\hline \multirow{3}{*}{$\begin{array}{l}\text { Penge- } \\
\text { tahuan }\end{array}$} & \multicolumn{6}{|c|}{ Tingkat Kecemasan } & \multirow{3}{*}{$\begin{array}{c}p- \\
\text { value }\end{array}$} \\
\hline & \multicolumn{2}{|c|}{ Ringan } & \multicolumn{2}{|c|}{ Sedang } & \multicolumn{2}{|c|}{ Berat } & \\
\hline & $\mathrm{f}$ & $\%$ & $\mathrm{f}$ & $\%$ & $f$ & $\%$ & \\
\hline Kurang & 3 & 7,5 & 2 & 5 & 1 & 2,5 & 0.001 \\
\hline Cukup & 12 & 30 & 13 & 32,5 & 2 & 5 & \\
\hline Baik & 2 & 5 & 1 & 2,5 & 4 & 10 & \\
\hline Jumlah & 17 & 42,5 & 16 & 40 & 7 & 17,5 & \\
\hline
\end{tabular}

Berdasarkan tabel 3 dapat

disimpulkan bahwa ada hubungan bermakna antara pengetahuan dengan tingkat kecemasan remaja putri di SMP Negeri 13 Kota Jambi dalam menghadapi menarche dengan $p$ value 0,001 (CI 95\%).

\section{SIMPULAN}

Dari hasil penelitian tentang Hubungan Pengetahuan dengan Tingkat Kecemasan Remaja Putri Menghadapai Menarche didapatkan kesimpulannya adalah sebagai berikut:

Sebagian besar didapatkan sebanyak (42.5\%) orang dengan pengetahuan baik tentang haid pertama (menarche), sebagian besar didapatkan sebanyak (75\%) orang dengan kecemasan tentang haid pertama (menarche) sedang, ada hubungan bermakna antara pengetahuan dengan tingkat kecemasan remaja putri dalam menghadapi haid pertama (menarche).

Hasil penelitian ini diharapkan dapat memberikan kontribusi dalam peningkatan pengetahuan remaja tentang kesehatan reproduksi terutama persiapan menstruasi dalam bentuk program sekolah yang bekerja sama dengan Puskesmas setempat. Upaya peningkatan pengetahuan tersebut juga dapat dilaksanakan oleh dosen dalam bentuk pengabdian kepada masyarakat yang dilaksanakan di sekolah dengan sasaran remaja.

\section{DAFTAR PUSTAKA}

Dariyo, Agoes. 2004. Psikologi Perkembangan Remaja .Bogor :Ghalia Indonesia

Ginarhayu. 2014. Analisis Faktor-faktor yang Berhubungan dengan Usia Menarche Remaja Putri (9-15 tahun) Pada Siswi Sekolah Dasar dan Sekolah Lanjut Tingkat Pertama di Jakarta Timur pada Tahun 2004. Tesis FKM UI, Depok

Imam. (2012). Persiapan Menarche Untuk Remaja Putri. Semarang : UNDIP

Judha Dkk. 2009. Obstetri Patologi Untuk Mahasiswa Kebidanan Dan Keperawatan. Jakarta : Nuha Medika Kartono, K.(2006). Psikologi Wanita. Bandung: Mandar Maju

Llewellyn-Jones, D. (2005). Setiap Wanita: Panduan Terlengkap tentang Kesehatan, Kebidanan \& Kandungan. Delapratasa

Mar'at, Prof .Dr. Samsunuwiyati. 2005. Psikolinguistik Suatu Pengantar. Bandung: Refika Aditama.

Nainggolan, E., \& Tambunan, D. (2013). Tingkat Kecemasan Orang Tua Menghadapi Perubahan Perilaku Remaja Pada Masa Pubertas Di Kelurahan Balige 3 . Diperoleh tanggal 18 Juni 2017, dari http://www.akperhkbp.ac.id/wpconte 
nt/uploads/2013/07/JurnalKeperawata n-Akper-HKBP-Balige-Vol- 1 -No$1 . \mathrm{pdf}$

Prawiroharjo, S. 2012. Ilmu Kebidanan. Jakarta: Yayasan Bina Sarwono Prawirohardjo

Proverawati dan Misaroh, (2007). Gambaran Pengetahuan remaja putri megenai menarche dan cara menghadapinya di SMPN 3 palembang.

Rumini, Sundari. 2004. Perkembangan Anak dan Remaja. Rineka Cipta.: Jakarta. 